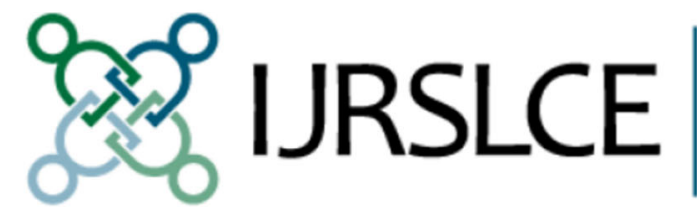

International Journal

for Research on

Service-Learning \&

Community Engagement

\title{
A Grounded Theory Investigation into the Process and Effects of Service Learning in Counselor Education
}

\author{
Joseph A. Stewart-Sicking \\ Jill L. Snodgrass \\ Rochelle Pereira \\ Wairimu W. Mutai \\ Robin Crews
}

This article was originally published at:

https://journals.sfu.ca/iarslce/index.php/journal/article/view/4/8

Recommended Citation

Stewart-Sicking, J. A., Snodgrass, J. L., Periera, R., Mutai, W. W., \& Crews, R. (2013). A Grounded Theory Investigation into the Process and Effects of Service Learning in Counselor Education. International Journal of Research on Service-Learning and Community Engagement, 1(1). 47-60. 


\title{
A Grounded Theory Investigation into the Process and Effects of Service- Learning in Counselor Education
}

\author{
Joseph A. Stewart-Sicking \\ Jill L. Snodgrass \\ Rochelle Pereira \\ Wairimu W. Mutai \\ Robin Crews \\ Loyola University Maryland
}

\begin{abstract}
Service-learning is an approach to experiential learning that is relatively unexplored among graduate students. The authors of this study sought to understand the process and effects of service-learning among 76 graduate counseling students enrolled in an "Introduction to Community Counseling" course over three semesters, 40 of whom engaged in service-learning. Analyzing students' reflection papers, projects, and blog entries via a grounded-theory approach, the study generated a model of how service-learning impacted these students' learning and sense of counselor identity. Students went through a process of development: They began with personal engagement, became overwhelmed, readjusted their expectations, and then reconstructed their individual counselor identities.
\end{abstract}

Keywords: service-learning; counselor education; grounded theory

The 2009 Council for Accreditation of Counseling and Related Educational Programs (CACREP) Standards "represent a significant change from content-based standards to competency-based standards" (Gehart, 2008, para. 1). This necessitates applied and experiential pedagogies that enable students to engage in dialectical discourse between the textbook/classroom and the "real world." In addition, the 2009 CACREP Standards emphasize the importance of social justice, advocacy, and multicultural competencies in counselor education and practice. Service-learning is one method for attending to these standards, as it helps students to recognize "that context matters, that stereotypes may not reflect reality, that multiple viewpoints have merit, that social problems have complex etiologies, and that solutions come from dialogue and cooperation" (Brandenberger, 1998, p. 77).

Service-learning emerged in the work of Robert Sigmon in the 1960s as an instructional method for integrating community service experiences into the learning environment in ways that foster citizenship (Rocheleau, 2004; Sigmon, 1996). Though the term "service-learning" was coined in 1967, Kendall's (1990) literature review evinced 147 derivations or understandings of the term, some focusing on it as a pedagogical approach and others as a philosophy. Amidst a plethora of definitions, we understand service-learning as a "course-based, credit bearing educational experience in which students (a) participate in an organized service activity that meets identified community needs, and (b) reflect on the service activity in such a way as to gain further understanding of course content, a broader appreciation of the discipline, and an enhanced sense of personal values and civic responsibility" (Bringle \& Hatcher, 2009, p. 38). Since the 1960s, sustained scholarly study among undergraduate populations evidences significant gains for service-learning students, including an enhanced awareness and ability to deal with social problems (Batchelder \& Root, 1994; Roschelle, Turpin, \& Elias, 2000), increased civic responsibility (Hunter \& Brisbin, 2000; Myers-Lipton, 1996), and an increase in critical thinking ability over the semester (Parker-Gwin \& Mabry, 1998). Other researchers have reported that students who engaged in service-learning activities indicated a greater 
interest in future community service (Astin \& Sax, 1998; Kollross, 1997) and significant increases in concern, activism, and attitudes related to world hunger and homelessness (Hattery, 2003; Nnakwe, 1999).

For over a decade, the discipline of counselor education has given increased attention to pedagogy and the role of contextual teaching (see Granello, 2000). We contend that service-learning is a viable pedagogy for addressing the 2009 CACREP Standards, as it enhances counselor identity formation and fosters social involvement. The available literature illustrates how numerous counselor education programs have incorporated service-learning in an effort to provide students with a prepracticum, field-based experience (Barbee, Scherer, \& Combs, 2003; Jett \& DelgadoRomero, 2009), address the development of multicultural and advocacy competencies (Baggerly, 2006; Burnett, Hamel, \& Long, 2004; Murray, Pope, \& Rowell, 2010; Stadler, Suh, Cobia, Middleton, \& Carney, 2006), lower anxiety and increase self-efficacy of counselors-in-training (Barbee, Scherer, \& Combs, 2003), and teach family-systems theory (Murray, Lampinen, \& KelleySoderholm, 2006) and substance abuse (Arnold \& McMurtery, 2011). Yet, only a small subset of the available body of literature employs empirical methods, drawing upon qualitative (Burnett, Long, \& Horne, 2005; Jett \& Delgado-Romero, 2009) and quantitative data (Barbee, Scherer, \& Combs, 2003). This study, however, is distinctive due to the rigor of its empirical method, employing a grounded-theory methodology to examine service-learning's impact among graduate students enrolled in a community counseling course. We attempted to examine several research questions that are at the heart of expanding conceptions of counseling and counselor education:

1. How does service-learning impact students' developing sense of counselor identity?

2. In what ways do students link their own and others' service-learning experiences to their working theories of counseling, understandings of professional ethics, and conceptions of social justice and advocacy?

3. How do students navigate their role as counselor within systems, structures/powers, and principalities?

By addressing these questions, we hope to expand the research base related to service-learning endeavors among graduate students in counselor education in order to gain a fuller understanding of the benefits and limitations of this unique form of instruction for future counseling practitioners.

\section{Methods}

\section{Theoretical Framework}

There are many approaches to qualitative research, and it is important to specify the theoretical and philosophical framework in which any given study is conducted so as to judge its quality. This study was rooted in a constructivist research perspective, which sees knowledge as actively constructed through language and denies the distinction between the knower and known, and facts and values (Duffy \& Chenail, 2009). Thus, instead of aiming for traditional markers of excellence such as internal and external validity, which presuppose a disengaged, positivist research perspective, this study pursued Guba and Lincoln's (1989) markers of quality in qualitative research: fairness, honoring different constructions; ontological authenticity, improving each participant's worldview; educative authenticity, opening participants to others' constructions; and catalytic authenticity, leading to some action based on the analysis.

The specific research method used in this study was grounded theory, "a qualitative research method that uses a systematized set of procedures to develop and inductively derive grounded theory about a phenomenon" (Strauss \& Corbin, 1990, p. 24). The particular approach was adapted from constructivist grounded theory as developed by Charmaz (2006). A grounded-theory method 
develops detailed or "thick" analytic categories from qualitative data by constantly refining the nuances of these categories through comparison with data encountered as the analysis continues. Grounded theory is distinct among qualitative approaches for the stress it places on identifying the processes and contexts through which major analytic categories develop and influence one another. The result is a theory, grounded in the data, of how social reality is constructed in a particular situation.

\section{Design and Participants}

This study followed a case-study design (Creswell, 2009), focusing in detail on the impact of service-learning on graduate students enrolled in "Introduction to Community Pastoral Counseling" during the fall semesters of 2007, 2008, and 2010, at a private, Roman Catholic university in the Eastern United States. Typically, students enroll in the course during their first or second semester, but all students must complete the course prior to registering for the clinical practicum. With the consent of students and administrators at partnering institutions in which students did service, we collected data from 76 students. Of the 76 students, 15 were male and 61 were female. Sixty-six students were U.S. citizens, and 10 were international students. Student ages ranged from 23 to 65, with a mean age of 42. Fifty-one students were European American, 16 African American/Black, seven Asian/Pacific Islander, one Hispanic, and one whose race/ethnicity was not given. Consent was obtained by verbally discussing with students their openness to analysis of their written reflections. This occurred at the first class. Students were invited to opt out of having their work analyzed in part or in total without penalty by informing the instructor verbally or in writing at any point in the course. The syllabus explained the above information in written form and was considered a contract with the students. According to the University's institutional review board, normal class assignments are exempt from signed informed consent. Nevertheless, all quotes are reported anonymously and confirmation/comment was sought from students whose quotes are included. All students chose to take part in the study.

As service-learning was an optional component of this course, 40 of the students engaged in 20 or more hours of service-learning at a community partner site in which they did nonclinical work with marginalized groups over the course of the semester. The remainder of the students (36) chose to complete additional course readings on counseling and social justice in lieu of service-learning hours. All of the students participated in small discussion groups for the purpose of reflecting upon the readings and service-learning experiences. Each small group contained service-learners and nonservice-learners. Thus, between small-group, class, and online discussions, every student was given the opportunity to reflect on his or her own and/or classmates' service-learning experiences. This arrangement made service-learning one of the core instructional techniques of the course.

The lectures and readings for the course approached issues of prevention and advocacy in counseling using an ecological framework (see Conyne \& Cook, 2004) that provides ways to conceptualize different systemic influences and interventions on clients ranging from distal to proximal. To triangulate sources of data (Flick, 2006), a wide spectrum of student work was collected electronically and analyzed. The bulk of the data was derived from weekly, online reflection essays in which students responded to the following prompts: "What really got me thinking?"; "How did it affect me?"; "How does it relate to what I am learning in class?"; and "How might it affect what I do in the future?" Service-learners responded to these queries based on their experiential learning, while non-service-learners reflected on their engagement with a review of literature on a topic of their choosing. All students were required to offer at least two responses to others' reflections. Additional data were gathered through a final reflection in which students responded to the prompts: "What is the most important thing I learned this semester?"; "Why is it important?"; and "How will it impact my work as a counselor?" Finally, data were collected through 
the analysis of a final paper in which students were asked to address the role of counseling in promoting a just society.

\section{Data Analysis}

Data were electronically entered into NVivo 8 qualitative data-analysis software and examined using grounded-theory approaches as described by Charmaz (2006). Data were initially coded line-by-line to summarize and define emerging categories, with special attention paid to the processes linking them. This analysis broke the data apart into hundreds of individual codes representing meaning units and processes. The researchers then reassembled the data through focused coding and aspects of axial coding (Corbin \& Strauss, 2008), in which codes were refined and organized into categories and subcategories. Finally, theoretical coding was conducted to identify how these concepts were related to one another (e.g., causally, logically, temporally, structurally, etc.), and the emerging relationships were stated as a theory about the process, which was tested and refined on additional data until no new information emerged (saturation). Throughout this process, the researchers' working theories were written down and stored electronically using the memo function of NVivo, which provided both an audit trail and the basis for the written analysis.

To ensure fairness in the analysis (Guba \& Lincoln, 1989), the first and fourth authors conducted coding independently and shared their findings with one another, reaching consensus on any differences. The third author, a student in the 2008 class, provided a "participant check" on the analysis, as did three other students (one from each semester). Finally, the second author, a professor who incorporates service-learning in graduate counselor education, and the fifth author, an administrator with extensive experience in coordinating and developing service-learning courses, served as final voices in refining the analysis.

Table 1 illustrates the categories generated from the analysis of the writings of all 76 students, both service- and non-service-learners.

Table 1. Central Categories

\begin{tabular}{|c|c|c|}
\hline Category & Description & Example \\
\hline Connecting & $\begin{array}{l}\text { Moving from abstract to personal } \\
\text { engagement, with course concepts } \\
\text { facilitated by topics and stories that } \\
\text { connect with student's own narrative. }\end{array}$ & $\begin{array}{l}\text { "The reading hit pretty close to home this } \\
\text { week since it addressed domestic violence. I } \\
\text { felt sad and angry but also appreciative of } \\
\text { how much I have learned about this topic." } \\
\text { Female non-service-learner }\end{array}$ \\
\hline $\begin{array}{l}\text { Being } \\
\text { Overwhelmed }\end{array}$ & $\begin{array}{l}\text { Building a belief that an ecological } \\
\text { approach is untenable, leading to } \\
\text { discouragement and anxiety. Reinforced } \\
\text { by perceptions of complexity, resources, } \\
\text { entrenched problems, work outside the } \\
\text { therapy hour, and stories of the messiness } \\
\text { of real-world partners. }\end{array}$ & $\begin{array}{l}\text { "I was somewhat overwhelmed as I } \\
\text { considered the complexity of social needs } \\
\text { and response modalities and the myriad of } \\
\text { human, political, economic, and systemic } \\
\text { factors that impact community counseling." } \\
\text { Female service-learner }\end{array}$ \\
\hline $\begin{array}{l}\text { Adjusting } \\
\text { Expectations }\end{array}$ & $\begin{array}{l}\text { Adapting one's categories and standards } \\
\text { for ecological counseling through } \\
\text { noticing small ways to implement it, } \\
\text { creating more modest goals, and seeing } \\
\text { self as part of web of care. Facilitated by } \\
\text { having a conceptual framework and } \\
\text { increased self-efficacy through } \\
\text { experiences and modeling. }\end{array}$ & $\begin{array}{l}\text { "Prevention reminds me of the importance of } \\
\text { being involved in a network of other helpers, } \\
\text { rather than an island of helping unto itself. I } \\
\text { tend toward the solitary, but for my own } \\
\text { sanity and for the sanity of my clients, I want } \\
\text { to be a resource capable of pointing them to } \\
\text { other resources." Male non-service-learner }\end{array}$ \\
\hline
\end{tabular}


Table 1. (continued)

\begin{tabular}{|c|c|c|}
\hline Category & Description & Example \\
\hline $\begin{array}{l}\text { Reconstructing } \\
\text { Counselor } \\
\text { Identity }\end{array}$ & $\begin{array}{l}\text { Constructing a new definition of } \\
\text { professional counseling that includes } \\
\text { elements of the ecological approach. }\end{array}$ & $\begin{array}{l}\text { "The impression persists that for counselors } \\
\text { the primary arena of intervention is the } \\
\text { personal counseling session-individual, } \\
\text { couple, family, or group. How would it be if } \\
\text { we, as pastoral counselors could look on } \\
\text { ourselves as agents of 'social and not merely } \\
\text { personal change'? ... I believe that if our } \\
\text { identity as counselors arose from this } \\
\text { background, then this vision would permeate } \\
\text { all our interventions-even those at the } \\
\text { strictly individual and personal level." Male } \\
\text { service-learner }\end{array}$ \\
\hline
\end{tabular}

\section{Limitations and Researcher Reflexivity}

One limitation of this study was its focus on the class rather than on individual students. The findings are not meant to distinguish the experiences of students who engaged in service-learning from those who did not. As Werner (1998) indicates, service-learning is most effective when it is voluntary. The goal is not the imposition of values; moreover, service that is not freely given cannot truly be called service (Werner, 1998). Therefore, we contend that non-service-learners also benefited from the engagement and action-reflection of their peers. Thus, this study is intended to analyze the impact of service-learning upon the class and its processes. As such, the findings are meant to help counselor educators to consider the contributions of service-learning-in light of the 2009 CACREP Standards - to counselor education. We are interested in examining how this pedagogy influences understanding of counselor identity and the role of civic engagement for the class and its participants, but not for individual students.

Second, some readers may take issue with the biases of the citizenship framework inherent within service-learning philosophies. However, it is our position that the 2009 CACREP Standardswith which accredited programs must comply-promulgate similar conceptions of citizenship. Therefore, we assume that a shared ethic of responsibility exists among research participants, readers, and the authors, though not necessarily shared by the wider culture.

Third, the study was conducted in an institutional environment highly supportive of servicelearning and social justice. The University has a Center for Community Service and Justice whose mission is to support engaged scholarship, including training and supporting faculty who wish to use service-learning in their courses. While this support likely aided in the process of developing and refining the course, we believe that it is unlikely that this aspect of the University's mission influenced the type of students involved or the dynamics of their experience. In fact, as graduate students, few participants were even aware of the Center. A more important limitation to consider is that the participants all chose to enroll in a pastoral counseling program, which would seem to indicate an affinity for more holistic care of clients.

Finally, as the data analyzed consisted of written reflections and assignments, our biases may influence our reading of the material. In addition, such written material did not afford us the opportunity to clarify meaning or import, since the communication was unidirectional. For this reason and for the sake of transparency, it is important for us to acknowledge our own standpoints, which both enabled and influenced our understanding of the data. The first author was the instructor for all three semesters of the course being studied, and he designed that course including its servicelearning component. The second author has taught the same course and also incorporates servicelearning into her instruction. The third author was a student in the course and took part in the servicelearning. The fourth author has taught the same course but not using service-learning methods. The 
fifth author was a university administrator and coordinator of service-learning programs. All of us would describe ourselves as supportive of the use of service-learning in teaching graduate and professional students, and all of us would describe ourselves as supportive of efforts to give increased attention to issues of advocacy and social justice in counseling.

\section{Results}

Similar to Jett and Delgado-Romero's (2009) study, this study indicates the important role of service-learning in counselor professional and identity development. However, whereas Jett and Delgado-Romero (2009) utilized a phenomenological single-study case design, we used a groundedtheory approach to explicate a theory of how counselor identity is strengthened through servicelearning. In accordance with grounded theory (Charmaz, 2006), the resulting theory is not derived from the data but is a construction of the reality evidenced by the data. Figure 1 depicts the theory constructed through the data analysis.
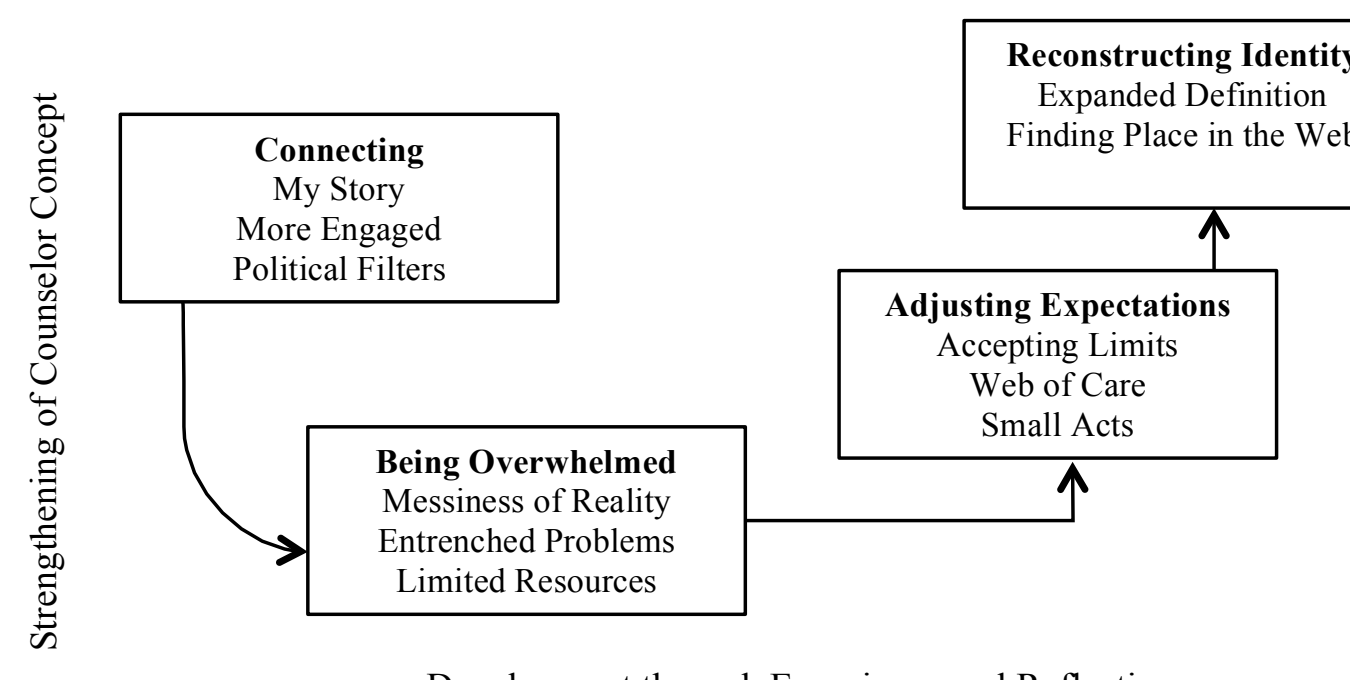

Finding Place in the Web

Being Overwhelmed

Messiness of Reality

Entrenched Problems

Limited Resources

Development through Experience and Reflection

Figure 1. Developing counselor identity through service-learning.

Categories are arranged spatially to show the process through which students' sense of counselor identity changed over time. Though each category will be addressed in greater detail, the findings indicate that students began the course with a moderate sense of counselor identity. They began connecting with service-learning-their own and their peers'-by relating it to theoretical knowledge, past experiences, and political beliefs and values. Through discussions and reflections on service-learning experiences, students became overwhelmed with the scope and complexity of an ecological model of counseling and the recognition of systemic influences on problems and circumstances presented in counseling. This coincided with decreased strength and stability of counselor identity. To work through this overwhelmed feeling, students began to adjust their expectations of themselves and of the counseling profession. These adjustments seemed to aid students as they began to articulate a new sense of counselor identity that matched their own sense of call to the profession but also the broader ecological perspective. This resulted in a strengthened counselor identity and understanding of the discipline of counseling, with greater awareness of the importance of multicultural competencies, social justice, and advocacy. 


\section{Connecting}

As with any class, students entered the course with a variety of initial understandings and experiences regarding the relationship between social action and counseling. These understandings and experiences formed their initial baselines for engaging the class, and this initial engagement tended to be intellectual and hypothetical instead of personal and concrete. Yet, as the class progressed, students experienced personal connections with the content through recalling their own experiences or sharing stories about service-learning. As these personal connections developed, the abstract story of the course became "my story." As one non-service-learning student reflected in a discussion of a literature review assignment on prevention and barriers to counseling:

[Domestic violence] is profoundly relevant to someone close to me, and that person's experience has shaped my life. . . . Now, finally, I had found an issue that engaged my heart, not just my head, in the central issues of this class. I have a concrete example of something meaningful to me that cries out for prevention and advocacy. In doing the assignment, I felt my imagination and my creativity and my passion for change becoming activated. I was energized — at last I am energized.

While this pattern of connection was present in almost all students, it took a specific form among the majority of service-learners in which they became quite engaged, doing extra research on class material that might help their service-learning sites. Approximately one-third of non-service-learning students were not so enthusiastic, struggling with whether a more socially engaged vision of counseling was what they "signed on for" in choosing this profession over others, such as social work. The theory derived in this study was equally applicable to these non-service-learners in that it represents the mutual social construction of the class experience shared with their peers and developed through conversations, but such students were limited to forging connections from personal experiences not derived from community-based learning. Any divergence in the data between these two groups is noted in the results. A small but important minority of all students wondered whether this advocacy and justice-oriented vision of counseling matched their political philosophy. While few of these students mentioned political parties, they tended to bristle at being told that counseling has social justice implications: As one student stated, "counseling is an individual or small-group experience. It is a private matter, not a forum for organizing social action."

\section{Being Overwhelmed}

As service-learning students (as well as those non-service-learners with prior work experience in social service) continued to reflect upon and share the complexity and real ups and downs of their experiences, class members began to feel overwhelmed. One summed up her feelings by saying, "I was overwhelmed by a sense of helplessness and hopelessness at seeing the same group of individuals day in and day out at a homeless shelter/soup kitchen." Whereas they were once excited by the opportunities of approaching counseling in a new way, students began to believe that a more ecological and advocative approach could not work in the real world. They experienced the "messiness" of real people, some of whom did not even want the help being offered, and the less than ideal conditions at service-learning sites:

The walls need a fresh coat of paint, the rug needs to be replaced and everything furnishing the center looks like it has been donated several times over. While they have several computers, a fax machine and two printers, the equipment often acts up leading to an everyday battle between man and technology. 
Seeing this lack of resources led many students to wonder whether such entrenched problems could ever be solved. Another student commented, "I found this situation extremely disheartening. Here was a client with a need and a program to address the need but in his case the program did not have the comprehensive resources required to meet this client's needs." Comparing real-life situations to theoretical models from the texts (e.g., Conyne \& Cook, 2004) led students to wonder whether socially engaged counseling could ever work on a large scale. As one student reflected, she had an "overwhelming sense that only a handful of communities get to experience the best of what the field has to offer." Students found themselves in the unhappy position of seeming to have signed on to a losing battle.

\section{Adjusting Expectations}

To emerge from this overwhelmed state, students began to adjust their expectations downward for themselves and the counseling profession. They began to articulate that it was alright to accept one's own limits, since a single counselor is only one part of a web of care: "I cannot change the public health system," one student reflected. "There are many ways to advocate for change. I've come to accept that I need to embrace my strengths and advocate from that position." Students also began to identify that there are many small actions of advocacy that could collectively effect large-scale change. Moreover, they realized that perfect solutions are not necessary for advocacy to work:

When I realized that I do not have to carry the burden of other peoples' problems, a huge weight was lifted off of my shoulders. I can be an advocate for people, but I do not have to solve their problems. Coming to this realization has made me more energized for helping others to achieve their own goals.

Students' sense of being overwhelmed also diminished through employing the ecological framework in order to conceptualize how to approach clients, engaging in small-group student interactions, and realizing that one has, all along, "been involved in some form of advocacy at the grassroots level without realizing it." Students also built self-efficacy through discussing servicelearning experiences in which students could apply class material or see the successes of other counselors in doing more ecological counseling.

\section{Reconstructing Counselor Identity}

As students began to find ways to stop feeling overwhelmed, they began to reconstruct an expanded definition of counseling that was more ecological in approach - a change that many found exciting. Adhering to this new definition, they began to articulate some of the limitations of the traditional therapy hour as the sole focus of counseling:

I have been surprised to realize how important what goes on outside of therapy will be to my work. Of course, I have considered that therapy will include work with family systems and giving homework that will involve making some environmental or relational changes. However, though seemingly obvious, it is fresh knowledge for me to realize that many clients will be facing oppression that will make my tidy, little homework tasks impossible to implement in their real lives.

Many students also began to stress the importance of prevention and advocacy as counselor competencies, including political action when necessary; as one put it, "I used to think that as a counselor I have no business dealing with politicians or high profile people but now I know better." 
Yet, students also emphasized that they were not in this situation alone. They stressed the importance of being part of a web of diverse and skilled care providers who could share the work of prevention. This network allowed some students to feel at home with the seeming contradiction between their call to focus on individual counseling while still remaining aware of the need for advocacy and social justice: "I think it is important to know the resources, refer out to people who specialize in those fields, and stick with what we have been trained to do-mental health counseling." For others, the experience of service-learning also led to a new sense of call within the counseling profession - one that included much more work with marginalized groups.

In the end, the service-learning and ecological focus of the course led students on a journey from connection to an overwhelmed state, to adjusted expectations that resulted, finally, in a reconstructed understanding of the vocation of counseling and a new sensibility of what this vocation might mean to society. One student's final reflection sums up this process well:

Perhaps the most valuable concept learned about in Community Counseling was the idea about the comprehensibility of mental health.... I must be frank and share that it was with resistance that I was required to take this course, and I was even more frustrated in the first few weeks when it seemed to me that the majority of the information for the course came from a sociological perspective. ... Identifying problems within the community has been an invaluable tool for me this semester as I became more involved and aware of the reciprocal interaction process... The course reminded me about the necessity to participate in my own community and society at large, realizing that the more each individual contributes to society, then the more society will have to offer each individual.

Figure 2 illustrates students' expanded understandings of the counseling profession.

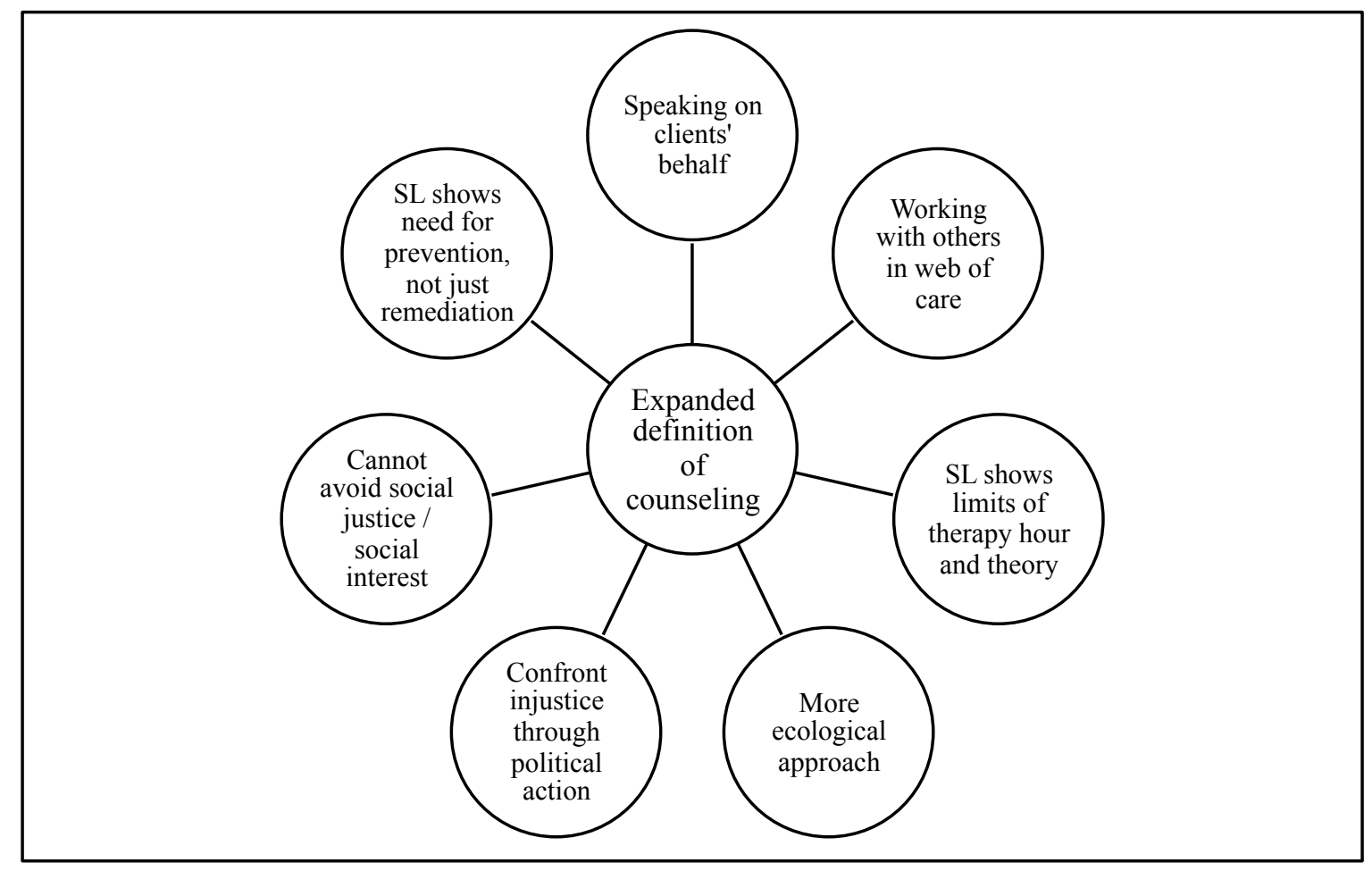

Figure 2. Expanding the definition of counseling. 


\section{Discussion}

\section{Evaluation of Findings}

Many steps were taken in this study to ensure adequacy of data (Morrow, 2005), including collecting data from multiple sections of the class being studied and analyzing different types of student assignments so that students' thought processes could be traced as they developed over time. These procedures led to an analysis that exhibited signs of theoretical saturation, an indication that adequate amounts of data had been collected. Moreover, negative cases (Corbin \& Strauss, 2008) - those data that did not fit the overall model - were considered explicitly, leading to the addition of a category dealing with how political differences could be a barrier to engaging with the class material. Despite these steps, the study was limited in some ways by the type of data it collected. Additional types of data such as ethnographic observation and interviews might have thickened the findings somewhat and added to the fairness (Guba \& Lincoln, 1989) of the analysis by adding more perspectives on the processes being studied. These data would also have had the benefit of being unattached to grading and thus less likely to be influenced by students wanting to please the instructor. While students appeared to be quite frank in their reflections, some positioning was unavoidable.

Turning to the findings themselves, the consensus among the authors and student auditors suggests that the analysis has done a fair job in reporting the experience of participants. Moreover, by sharing the findings with students, the study pursued ontological and educative authenticity (Guba \& Lincoln, 1989) by helping participants come to a better understanding of their experiences.

While qualitative researchers do not tend to speak of generalizing their findings, it is worth considering the extent to which findings might be transferable to other situations (Morrow, 2005). In the case of the current study, the processes of engagement, being overwhelmed, adjusting expectations, and reconstructing professional identity are likely to find analogues in other settings in which service-learning is pursued in conjunction with counseling coursework; however, certain specifics of this case undoubtedly influenced their shape. Students in this class were provided the ecological framework of Conyne and Cook (2004) to help conceptualize their experiences, and the relationship between service-learning and citizenship was explicitly addressed through lectures, readings, and assignments. Without these two aspects of the class, students may have been less quick to emerge from being overwhelmed in the direction of including issues of advocacy and social justice in their reconstructed definitions of counseling; instead, they may have chosen to retrench their definitions of professional counseling in the traditional therapy hour and resolve to work more closely with referral sources. Moreover, students enrolled in a pastoral counseling program at a university that is committed to engaged scholarship may have been more disposed - and had more support - to work through difficulties encountered along the way.

\section{Implications}

By making use of student reflections produced in the course of a service-learning class, this study provides a different perspective on the experience of service-learning than those studies that have used quantitative measures and retrospective interviewing. For instance, the process that emerged from the data shows many similarities to those seen by Schmidt (2000) and Peterson (1998), in which students involved in service-learning classes developed more self-efficacy, identity, and complexity in their worldviews. However, these outcomes only came after students passed through a state of being overwhelmed by the service-learning experience and subsequently readjusted their expectations. Counselor educators interested in effectively incorporating service-learning need to be prepared for the process by which such gains are realized.

This study also provides an instructive contrast to Jett and Delgado-Romero's (2009) study, which found no evidence that service-learning increased counseling students' attention to issues of 
social justice at the end of a course of study. While the current study cannot speak to whether students' expanded definitions of professional counseling will persist, it does suggest how attention to social justice in counseling might develop through service-learning classes and what steps counselor educators might take to encourage these processes.

Service-learning and structured reflection upon these experiences were helpful to all students (not just service-learners) in providing experiences through which students could make personal connections to theoretical material and build self-efficacy and confidence in the notion that a more ecological, socially engaged vision of counseling could work. However, there were key barriers to engagement, namely entrenched ideas of professional identity and perceptions of political mismatch. Counselor educators need to be prepared to engage with these barriers head on, discussing how social justice fits with counseling's professional vision and allowing students to articulate different visions of the just society beyond the current social welfare system that might guide them. Finally, counselor educators should be prepared to walk with students through the process of being overwhelmed. Students in this study tended to readjust their expectations of themselves and counseling on their own, but having a framework such as Conyne and Cook's (2004) ecological model proved helpful in giving students some way to link their passion for individual counseling with larger social systems.

The theory that emerged from this study offers significant implications for counselor education. First, faculty can prepare students for being overwhelmed by service-learning and normalize the process by naming this phenomenon when it emerges and pointing to how it is a crucial step toward a more mature definition of counseling. Second, faculty can encourage students to think of themselves as members of a web of care from the beginning of the course so that they can readjust their expectations of their own work and reconstruct their understanding of counselor identity as the course progresses. Finally, faculty can facilitate open discussion about the political and ethical commitments of the service-learning model and of advocacy in counseling, encouraging students to discuss how they move beyond any single party's philosophy. The first and second authors implemented these strategies and found that student reflections have deepened, resistance has decreased, and a richer sense of counselor identity has emerged.

The literature exploring prepracticum service-learning in counselor education programs has broadened in the last decade. As noted above, this study is unique in that it employs a groundedtheory method, in contrast to other related studies that use quantitative, single-case study and actionresearch methods. The advantage of grounded theory is that while it studies a particular issue in a bound setting, the theory generated is never finished or static but always ongoing and dynamic. Therefore, additional studies employing grounded theory will create a depth and breadth to the metatheory that cannot be achieved through other methodologies.

\section{Conclusion}

Service-learning is a potentially powerful tool for helping counseling students develop a vision for themselves and their profession that addresses issues of social justice and advocacy. By studying in detail the processes through which service-learning works, this study has provided counselor educators with a better understanding of how to employ service-learning as a critical pedagogy and reveals what the ups and downs of this process might look like. As the counseling profession continues to explore how it might work for social justice, service-learning could play a key role in this project. Moreover, as indicated by the emergent theory, students experienced the opportunity to be overwhelmed in the face of systemic injustices such as racism, discrimination, sexism, power, and oppression (CACREP, 2009). Through that experience they came to see the importance of referrals as well as the need for advocacy for policies, programs, and services (CACREP, 2009). They not only modified their approach to others but they amended their understandings of self and the profession of counseling. This acquisition of both knowledge and skill fulfills many of CACREP's 
58 | International Journal of Research on Service-Learning and Community Engagement

2009 Diversity and Advocacy Standards for Clinical Mental Health Counseling, thus leveraging the effectiveness of prepracticum coursework.

\section{Author Note}

This research was supported in part by a grant from the Center for Community Service and Justice, Loyola University Maryland.

\section{Correspondence}

Correspondence concerning this article should be addressed to: Joseph A. Stewart-Sicking, Department of Pastoral Counseling, Loyola Graduate Center, 8890 McGaw Road, Columbia, MD 21045; jastewartsicking@loyola.edu

\section{References}

Arnold, R., \& McMurtery, R. F. (2011). Integrating service learning into counselor education: Applications and implications. The Researcher: An Interdisciplinary Journal, 24, 59-74. Retrieved from http://1.jsucdn.com/researcher/wp-ntent/blogs.dir/335/files/2013/01/FullIssue.pdf

Astin, A. W., \& Sax, L. J. (1998). How undergraduates are affected by service participation. Journal of College Student Development, 39(3), 215-263. Retrieved from http://www.jcsdonline.org/home.html

Baggerly, J. (2006). Service learning with children affected by poverty: Facilitating multicultural competence in counseling education students. Journal of Multicultural Counseling and Development, 34, 244-255. doi: 10.1002/j.2161-1912.2006.tb00043.x

Barbee, P. W., Scherer, D., \& Combs, D. C. (2003). Prepracticum service-learning: Examining the relationship with counselor self-efficacy and anxiety. Counselor Education and Supervision, 43(2), 108-119. doi: 10.1002/j.1556-6978.2003.tb01835.x

Batchelder, T. H., \& Root, S. (1994). Effects of an undergraduate program to integrate academic learning and service: Cognitive, prosocial cognitive, and identity outcomes. Journal of Adolescence, 17, 341-355. doi:10.1006/jado.1994.1031

Brandenberger, J. W. (1998). Developmental psychology and service-learning: A theoretical framework. In R. G. Bringle \& D. K. Duffy (Eds.), With service in mind: Concepts and models for service-learning in psychology (pp. 68-84). Washington, DC: American Association for Higher Education.

Bringle, R. G., \& Hatcher, J. A. (2009). Innovative practices in service learning and curricular engagement. In L. Sandmann, A. Jaeger, \& C. Thornton (Eds.), New directions in community engagement (pp. 37-46). San Francisco, CA: Jossey-Bass.

Burnett, J. A., Hamel, D., \& Long, L. L. (2004). Service learning in graduate counselor education: Developing multicultural counseling competency. Journal of Multicultural Counseling and Development, 32(3), 180-191. doi: 10.1002/j.2161-1912.2004.tb00370.x

Burnett, J. A., Long, L. L., \& Horne, H. L. (2005). Service learning for counselors: Integrating education, training, and the community. Journal of Humanistic Counseling, Education and Development, 44, 158-167. doi: 10.1002/j.2164-490X.2005.tb00028x

Charmaz, K. (2006). Constructing grounded theory: A practical guide through qualitative analysis. Thousand Oaks, CA: Sage.

Conyne, R. K., \& Cook, E. P. (2004). Ecological counseling: An innovative approach to conceptualizing person-environment interaction. Alexandria, VA: American Counseling Association.

Corbin, J., \& Strauss, A. L. (2008). Basics of qualitative research $\left(3^{\text {rd }}\right.$ ed.). Thousand Oaks, CA: Sage. 
Council for Accreditation of Counseling and Related Educational Programs (CACREP). (n.d.). 2009 Standards. Retrieved from http://www.cacrep.org/template/index.cfm

Creswell, J. W. (2009). Qualitative inquiry and research design: Choosing among five traditions. Thousand Oaks, CA: Sage.

Duffy, M., \& Chenail, R. J. (2009). Values in qualitative and quantitative research. Counseling and Values, 53(1), 22-38. doi: 10.1002/j.2161-007X.2009.tb00111.x

Flick, U. (2006). An introduction to qualitative research $\left(2^{\text {nd }}\right.$ ed.). Thousand Oaks, CA: Sage.

Gehart, D. (2008). Assessing student learning and 2009 CACREP standards. Retrieved from http://www.counselingcompetencies.com/page5/page5.html

Granello, D. H. (2000). Contextual teaching and learning in counselor education. Counselor Education and Supervision, 39, 270-284. doi: 10.1002/j.1556-6978.2000.tb01237.x

Guba, E., \& Lincoln, Y. (1989). Fourth generation evaluation. Thousand Oaks, CA: Sage.

Hattery, A. J. (2003). Sleeping in the box, thinking outside the box: Student reflections on innovative pedagogical tools for teaching about and promoting a greater understanding of social class inequality among undergraduates. Teaching Sociology, 31(4), 412-427. Retrieved from http://www.jstor.org/stable/3211366

Hunter, S., \& Brisbin, R.A., Jr. (2000). The impact of service learning on democratic and civic values. PS: Political Science and Politics, 33(3), 623-626. Retrieved from http://www.jstor.org/stable/420868

Jett, S., \& Delgado-Romero, E. A. (2009). Prepracticum service learning in counselor education: A qualitative study. Counselor Education and Supervision, 49(2), 106-121. doi: 10.1002/j.15566978.2009.tb00091.x

Kendall, J. C. (1990). Principles of good practice in combining service and learning. In J. C. Kendall and Associates (Eds.), Combining service and learning: A resource book for community and public service ( $1^{\text {st }}$ vol.). Raleigh, NC: National Society for Internships and Experiential Education.

Kollross, C. A. (1997). Service learning and citizenship: Is there a connection? Unpublished master's thesis, California State University, Long Beach, CA.

Morrow, S. (2005). Quality and trustworthiness in qualitative research in counseling psychology. Journal of Counseling Psychology, 52(2), 250-260. doi:10.1037/0022-0167.52.2.250

Murray, C. E., Lampinen, A., \& Kelley-Soderholm, E. L. (2006). Teaching family systems theory through service-learning. Counselor Education \& Supervision, 46, 44-58. doi: 10.1002/j.15566978.2006.tb00011.x

Murray, C. E., Pope, A. L., \& Rowell, P. C. (2010). Promoting counseling students' advocacy competencies through service-learning. Journal for Social Action in Counseling and Psychology, 2(2), 29-47. Retrieved from http://jsacp.tumblr.com/post/2596189620/journal-for-social-actionin-counseling-and-psychology

Myers-Lipton, S. J. (1996). Effect of a comprehensive service-learning program on college students' level of modern racism. Michigan Journal of Community Service Learning, 3, 44-54. Retrieved from http://hdl.handle.net/2027/spo.3239521.0003.105

Nnakwe, N. E. (1999). Implementation and impact of college community service and its effect on the social responsibility of undergraduate students. Journal of Family and Consumer Sciences, 91(2), 57-61.

Parker-Gwin, R. P., \& Mabry, J. B. (1998). Service-learning as pedagogy and civic education: Comparing outcomes for three models. Teaching Sociology, 26(4), 276-291. Retrieved from http://www.jstor.org/stable/1318768

Peterson, E. A. (1998). What can adults learn from community service? Lessons learned from AmeriCorps. Community Education Journal, 25(1-2), 45-46. Retrieved from http://www.servicelearning.org/library/resource/1884 
60 | International Journal of Research on Service-Learning and Community Engagement

Rocheleau, J. (2004). Theoretical roots of service learning: Progressive education and the development of citizenship. In B. W. Speck \& S. L. Hoppe (Eds.), Service-learning: History, theory, and issues (pp. 3-12). Westport, CT: Praeger Publishers.

Roschelle, A. R., Turpin. J., \& Elias, R. (2000). Who learns from service learning? American Behavioral Scientist, 43(5): 839-847. doi:10.1177/00027640021955630

Schmidt, B. C. (2000). The service sojourn: Conceptualizing the college student volunteer experience. Unpublished doctoral dissertation, University of Utah, Salt Lake City, UT.

Sigmon, R. L. (1996). A service-learning timeline. In R. L. Sigmon (Ed.), Journey to servicelearning: Experiences from independent liberal arts colleges and universities (pp.158-166). Washington, DC: Council of Independent Colleges.

Stadler, H. A., Suh, S., Cobia, D. C., Middleton, R. A., \& Carney, J. S. (2006). Reimagining counselor education with diversity as a core value. Counselor Education and Supervision, 45(3), 193-206. doi: 10.1002/j.1556-6978.2006.tb00142.x

Strauss, A. L., \& Corbin, J. (1990). Basics of qualitative research: Grounded theory procedures and techniques. Thousand Oaks, CA: Sage.

Werner, C. M. (1998). Strategies for service-learning: Internationalization and empowerment. In D. K. Duffy \& R. G. Bringle (Eds.), With service in mind: Concepts and models for servicelearning in psychology (pp. 119-127). Washington, DC: American Psychological Association. doi: $10.1037 / 10505-008$ 